"Les organismes trouvés, après que le dépôt en̂t été bien coloré par l'éosine, ont été des germes de champignons de diverses sortes multipliant comme tels et produisant du mycélium." 2

Malheureusement, en modifiant encore sa technique, le Dr. Bastian ne devait pas tarder à fournir de nouvelles armes à ses contradicteurs. Il commit, en 1915, l'imprudence de se servir de "solutions vieillies," pullulant d'organismes accidentels, dont la découverte au moment de l'ouverture des tubes était une grave cause d'erreur,-bien que ces organismes aient été tués par la stérilisation. Telle est l'origine des préparations contenant des Conferves que Massee détermina comme Cladosporium, et que nous eûmes l'occasion d'examiner à notre laboratoire, le Dr. Bastian nous les ayant communiquées. D'un autre côté, le $\mathrm{Dr}$. Bastian ouvrit des tubes en incubation, y introduisit de la tyrosine stérile, les referma, et, après un nouveau laps de temps, en examina le contenu. Nous ne nous arrêterons pas aux résultats ainsi obtenus, qui, sans porter atteinte aux expériences antérieures, n'offrent plus les garanties nécessaires en si délicate matière.

On s'est aperçu que nous réservions notre opinion sur la nature exacte des corpuscules synthétiques rencontrés. Par leur morphologie, leurs dimensions, leurs réactions colorantes, ces corpuscules sont identiques id des microbes. Les essais de culture sont souvent nésatifs ou douteux; mais un tel argument n'a pas une valeur technique absolue, car il suffit de parconrir n'importe quel bon Traité de Bactériologie pour se rendre compte que plusieurs espèces de microbes n'ont jamais été cultivées avec succès, faute sans doute d'avoir trouvé un milieu favorable à leur multiplication. Certains corpuscules synthétiques, examinés au microscope sans fixation, - en particulier les formes bacillaires des variétés de solution blanche et de nos solutions III. et IV.,-sont animés de mouvements browniens; on sent que nous sommes ici à l'extrême limite des phénomènes physiques et des phénomènes biologiques. Quant aux réactions biochimiques des corpuscules, elles fournissent un chapître intéressant à nos études complémentaires sur les expériences du Dr. Bastian. Malgré l'opinion contraire du regretté Professeur les corpuscules synthétiques ne renferment aucune trace de corps protéiques; cependant, en diverses circonstances, ils se comportent comme des ferments. Les formes de notre solution $I$. exercent une action peroxydasique légère sur le pyrogallol en présence d'eau oxygénée; il apparaît alors de la purpurogalline, et l'action catalytique peut être entièrement supprimée par l'addition d'une trace d'acide chlorhydrique, azotique ou sulfurique. Les corps microboïdes de notre première variante de "solution blanche" intervertissent faiblement le sucre de canne: comme la silice colloidale domine dans leur composition chimique, cette constatation nous a conduits $t$ étudier le pouvoir intervertissant des hydrosols de silice, et nous avons publié les résultats de nos recherches à cet égard.:

En résumé, les formes organoïdes obtenues par les méthodes du Dr. H. Ch. Bastian, ou par des techniques similaires, ne prouvent pas la possibilité d'obtenir de novo, dans des solutions salines stérilisées, des organismes microscopiques assimilables de tous points aux organismes albuminoïdes que nous manipulons couramment dans les laboratoires de Bactériologie. Toutefois, le Dr. Bastian ne s'est nullement mépris en pensant que ses expériences étaient susceptibles de jeter de la lumière sur "l'origine de la vie." Au point de vu biophysique, ces recherches sont d'un énorme intérêt, et suffiraient pour assurer une gloire durable au grand pathologiste britannique qui les a initiées. Elles mettent en évidence simultanément, avec une complexité assez comparable à celle de la vie organique, les facultés d'organisation, d'accroissement, de réaction brownienne et de catalyse biochimique de l'état colloïdal. Il suffit que cet état remarquable de la substance se trouve réalisé par le jeu des actions chimiques les plus simples, pour que se dessinent les caractères structuraux et dynamiques les plus généraux de la vie, en dehors de toute considération d'ordre chimique. Et cela me rappelle que c'est également à un savant britannique, l'illustre physicien Sir Thomas Graham,

2 The Production at Will of Either Fungus Germs, Flagellate Monade, or Amcebx from the Ultimate Segments of Small Masses of Zooglca, reprinted from Nature, Dec. 24th, 1914. Postscript: New Details Concerning Tube Experiments on the Origin of Life, by $\mathbf{H}$. Charlton Bastian.

3 Comptes-rendus de l'Académie des Sciences de Paris (Séance du 28 Octobre, 1918) que la science biophysique est redeveable de cette géniale indication: "L'état colloidal apparait comme la source première de la force qui se manifeste dans les phénomènes de vitalité."-Je suis, Monsieur, très sincèrement vôtre

Institut de Biophysique, Paris, 11 Juin, 1919. ALBERT MARY.

* * We gladly publish Dr. Mary's admirably Iucid account of the experiments carried out by himself and his brother, employing at first Bastian's "white solution," and continuing with others of their own devising. Their results were such as to move Bastian in 1914 to write expressing surprise at the high degree of success attained, which he was fain to contrast with his own large percentage of negative results. Dr. Mary, it will be noted, expressly reserves his opinion upon the nature of his "synthetic corpuscles." They cannot be cultivated, possibly, he suggests, for want of a suitable medium. Containing no protein, they yet act as catalysts, liberating oxygen from peroxide and inverting sugar. What ever the origin or nature of these bodies, Dr. Mary is right in regarding them as a remarkable form of the colloidal state. -ED. L.

\section{EPIDEMIC PERINEPHRIC SUPPURATION.}

\section{To the Editor of THE LANOET.}

SIR,-It has been very gratifying to me to have received, in response to my letter to THE LANOET on June 7 ch sufficient information to prove that perinephric suppuration is fairly widespread at the present time. My suggestion that it was a relic of "influenza" was meant to be taken in a very wide sense, in that the recent epidemic probably covered a variety of infections.

Sir Thomas Horder's view that there is a particularly virulent strain of Staphylocvoous aureus being spread about is one that I certainly agree with. Boils have long been looked on as the focus of infection in these cases, but I have been unable to trace such a focus in any of my cases, except possibly the one who had been operated upon for fistula. During the last four jears I have had many cases of officers and soldiers suffering from boils and impetigo, but no cases of perinephric abscess except one, and that was, I think, about two years ago.

Dr. Adolphe Abrahams's cases resemble mine almost exactly. Two of his cases, he states, had suffered from definite attacks of influenza. I wonder whether the apparent influenza symptoms were truly those or only the pyrexia and general illness due to a staphylococcal infection of the perinephric tissue. As the swelling in the region of the kidney is slow in developing, it is likely that the pyrexia without any definite symptoms might be attributed to influenza. It is clear that Dr. Abrahams (and I plead guilty to the same) is suspicious of a combination of pyrexia and pain in the region of the kidney in view of his previous cases.

Mr. Forbes Fraser, of Bath, has been kind enough to write to me about 12 similar cases he met with in France and Germany as consulting surgeon. Shortly, nine of the cases which were investigated bacteriologically were due to $S$. aureus, and none of them had urinary symptoms. One of them was very ill, and diagnosis of typhoid or generalised tubercle had been made, but tenderness and pain in the loin led Mr. Fraser to suggest perinephric abscess, which it turned out to be. Another case resembled my worst one in that the liver was pushed down by a retroperitoneal abscess. It is interesting, too, to hear from Mr. Forbes Fraser that another staphylococcal disease, acute osteomyelitis, is commoner among troops on the Rhine than in normal times, and he says that skin infections were common and of a severe and protracted type. Mr. C. H. Allen, of Nottingham, has also written to me about three cases under his care in the last two months, in each of which the perinephric abscess is supposed to have followed an attack of influenza. $\mathrm{Mr}$. Warren Low very kindly got his house surgeon, Mr. F. A. Williamson, to write to me about a perinephric abscess under his care at the present moment with a mixed infection of staphylococci and streptococci.

Dr. W Pasteur's letter of June 14th is also very interesting in that he reports 30 cases. From what I can gather, the early stages of my cases have been very similar to his. I think I have answered his objection to my suggestion about inflnenza. At the same time, I cannot find any other sufficiently convenient and expressive term as "epidemic."

Sioce writing the above, I have operated upon yet another case at the Royal Free Hospital, sent to me by 
Mr. A. M. Sully, of Claygate. I am strongly of the opinion that epidemic perinephric suppuration is at the moment fairly common; that it is due to infection with Staphylococous aurews of an increased virulence; that the focus of infection may be boils, but in the majority of cases such cannot be traced any more than in acute osteomyelitis. An acute illness coming on with pyrexia and pain in the lumbar or hypochondriac region and persisting for a period of two to three weeks or longer should be examined carefully and frequently for signs of a swelling in the region of the kidney. If such is present or there are cedema and stiffness of the muscles and a leucocytosis, it is the right procedure to explore that region for pus. I am, Sir, yours faithfully,

Upper Wimpole-street, W., June 23rd, 1919. JoSEPH CUNNING.

\section{MENTAL DISORDERS ASSOCIATED WITH OLD AGE. \\ To the Editor of THE LANOHT.}

Srn,-In his interesting clinical lecture under this heading which appears in THE LANCET of June 14th I note that Sir George Savage left unsaid one of the greatest reasons for mental breakdown in elderly persons, especially in those who have given up active business life. In such patients the great factor in causation of mental breakdown is the absence of any hobby. Over and over again I have sean such cases, and to my questions, "Is the patient fond of reading? Does he play golf, or bowls, or croquet, or billiards, or cards ?" the answer has frequently been in the negative. After an active business life these persons find themselves with nothing to do, and, having to kill time as best they can, they soon break down, Introspection sets in, with morbid ideas, and unless a new and active life can be mapped out the end is inevitable. It is extraordinary how many business men have never been readers of anything but the newspapers, and how many of them take wo interest in any kind of games or care even for music. I feel sure that many of these cases, if taken in time, can be cured if a definite programme of occupation is insisted on.

I am, Sir, yours faithfully,

Lionel A. WeatherLT, M.D. Aberd.

Bournemouth, June 20th, 1919.

\section{THE SERVICES.}

\section{ROYAL NAVAL MEDICAL SERVICE.}

Temp. Surg. Lieut. H. Ellis, invalided on account of ill-health conracted in the service, to retain his rank.

To be Temporary Surgoon Lientenant: W. S. Sykes.

\section{ARMY MEDICAL SERVICE.}

Temp. Major-Gen. Sir A. A. Bowlby, K.C.M.G., K.C.V.O. (Lieut. Col., R.A.M.C., T.F.), relinquishes his temporary commission on se-posting

Temp. Col. W. N. Barron, C.M.G., M.V.O., relinquishes his commission and retains the rank of Colonel.

Col. F. J. Morgan, C.M.G., is placed on retired pay.

Lieut.-Col. S. G. Butler, D.S.O., to be Acting Colonel whilst specially employed.

\section{ROYAL ARMY MEDICAL CORPS.}

Lieut.-Col. G. E. F. Stammers, O.B.F., retires on retired pay.

Capt. J. E. Rusby resigns his commission.

Oapt. (acting Major) W.W. Treves retires, receiving a gratuity, and s granted the rank of Major.

Temp. Lieut. W H. Trethowan to be temporary Captain.

B. F. Howlatt, late Temporary Lieutenant, to be Lieutenant

Officers relinquishing their commissions: Temp. Hon. Lieut.-Col. S. S. Pringle on ceasing to serve with the Irish Counties War Hospital, and retains the honorary rank of Lieutenant-Colonel. Temp. Lieut. Col. W. Hind (Major and Brevet Lieut.-Col., T.F. Res.) retains the zank of C'eutenant-Colonel. Temporary Majors: S. G. Ógilvy, E. W. Hore (Lient.-Col., I.M.S., retiren). Temporary Majors retaining the rank of Major: S. W. Williams, J. Hall-Edwards, F. J. Stuart, F. N. G. Starr, J. C. Wright, J. N. Dobie. Temp. Hon. Major W. G. Harvey retains the honorary rank of Major. Temp. Capt. A. S. Burgess. Temporary Captains granted rank of Major: J. Burke, $R$. Scott, W. A R. B. Macfie. Temporary Captains retaining the rank of Captain: B. Pickering, J. Green, W. D. Kennedy, E. F. Greene, W. Cockcroft, G. L. Gall, D. N, Anton, M. Tang, G. Belev, H. M. Patterson, D. C. Robertson, C. J. B. Pasley, S. Wood, D. R. C. Shepcherd, O. W. Bateman, S. W. G. Ratcliff, K. Rogerson, G. T. Drummond, A. E. Bovcott, A. A. Straton, G. M. Mayberry J. W. Miller, H. B. James, V Glendinning, W. E. Tanner, $\mathbf{E}$. H. Moore, R. M. Miller, J. R. MeGregor, A. Merrin, J. F. Paul, G. A. Simpson, F. G. Milne, J. Tiahborne, R. Thorpe, R. H. Vereoe, H. V A. Gatchell, J. Dunbar, W. L Seott, J. Maclnnes, J. D. Mckelvie, J. Magner, D. F. Riddell,
S. S. M. Wood, P. J. Murphy, R. A. Parsons, A. Mackintosh, A, E. S Marti,, E. B. Hill, N. Gray, M. L. Hine, E. S. Miller, C. H Treadgold, J. G. Millar, H. H. Davis, A. D. 'I urnbull, J. S. Somerville W. Deane, A. Sunderland, G. E. Davidson, J. A. Mearns, J. G. Woolham, Vaile, B. N. M. Stalker, J. O. Smith, W. MacAdam, W. A. Shafto, W. B. Vaile, B. N. Norman, T. W. G. Johnson, G. C Swanson, J. B. O
Richards, T. C. A. Sweetnam, K. G. C.lquhoun. Temp. Hon. Capt. H Michards, T. C. A. Sweetnam, K. G. C.lquhoun. Temp. Hon. Capt. H retaining the rank of Lieutenant: R. Clark, W. S. Verdon, W. G. MacArthur.

J. E. Rusby, late Captain, R.A.M.C., to be Captain. SPECIAI RESERVE OF OFFICERS.

Captains relinquishing their commissions and retaining the rank of Captain:

Lieutenants to be Captains: A. E Jenkins, N. Da Ball, F. Miller, J. Peter, P. W. Putnam, R. H. Sutherland, M. D. Vint, G. S. L. Kemp Rennie, T. H. J. Douglas.

TERRITORIAI FORCE.

Captains (acting Majors) relinquishing their acting rank on vacating appointment of Deputy Assistant Director of Medical Services : J. M. Mune, W. H. Rowell. R. P. Anderson, W B. Keith. Captains (acting Majors) relinquishing their acting rank on ceasing
to be specially employed : O. H. Williams, J. M. Smith, L. West, T. J. Wright, A. M. Jones, J. Wood, J. F. MacIntosh, J. A. Willett.

Capt. (acting Major) J. 'l'ait to be acting Lieutenant.Colonel whilst specially employed.

Capts. G. L. Findlay, G. W. C. Hollist, St. A. Titmas, J. B. Bate to be acting Majors while specially employed.

Capt. W. B Keith to be acting Lientenant Colonel whilst specially employed.

Capt. (acting Major) C. H. J. Fagan to be acting Lieutenant-Colonel whilst specially employed.

Capts, A. K. Maclachlan and C. A. Raison to be acting Majors whilst prcially employed.

Capt. R. P. Ryan to be Major.

Ist London Sanitary Compıny: Lieut. H. H. Fowler to be Captain.

2nd London Sanitary Compan : Capt. (acting Major) S. H. Daukes

relinquisbes his acting rank on ceasing to be specially employed.

3rd Southern General Hospital : Capts. H. M. Clarke and W. B. Secretan are restored to the establishment.

2nd Western General Hospital : Capt. F. C. Moore is restored to the establishment on ceasing to hold a temporary commission in the R.A.M.C.

2nd Northern General Hospital : Major (acting Lieut.-Col.) W. H. M. Telling relinquishes his acting rank on ceasing to be specially employed.

North Midland Casualty Clearing Station: Major (temp Lieut.-Col.) A. R. Henchley, D.S.O., relinquishes his temporary rank.

\section{ROYAL AIR FORCE.}

Medical Branch.-Capt. F. A. Hampton, Capt. N. S. Gilchrist, and Lieut. F. S. Drewe are transferred to the unemployed list.

INDIA AND THE INDIAN MEDICAL SERVICE.

The Hon. Major-General C. Giffard, C.S.I., has been appointed chairman of the Manras Passage Control Committ ee for the Allotment of Passages to Europe from India. Major W. G. Hamilton. on return from military duty, has reverted to civil employment in Bengal. The following appointments have been made at the Ldhore Medical following appointments have been made at the Ldhore Medical
College: Lieut. Col. $\mathrm{E}$. V. Hago to be Protessor of Surgery; Major College: Lieut. Col. H. V. Hogo to be Protessor of Surgery; Major
R. H. B.tt, Professor of Operative Surgery; Major H. H. Broome, R. H. B.tt, Professor of Operative Surgery; Major H. H. Broome,
Professor of Anatomy; Capt. S. M. A. Faruli, a member of the Civil Professor of Anatomy; Capt. S. M. A. Faruki, a member of the Civil and Military Examination. Committee for examiling candidates in Hindustani. Lieut. A. H. McGregur has been ap. ointed as House
Surgeon at the J. J. Hospital, Bumbiy. Major C. C. Murison has Surgeon at the J. J. Hospital, Bumbly. Major C. C. Murison has been appointed Civil Surgeon, Belgaum. Major L. P. Stephen Administrative Medical Offic- $r$, Sind, in aditition to his miliAdministrative Medical Offe-r, Sind, in aditition to his mili tary duties. Major A. F. Hamilton has been appointed to act as physician in charge, Bai-Mothibai and Sir D. M. Petic Hospitals, and Professor of Midwifery, Grant Medical College, Bombay, vice
Lieut.-Col. S. C. Evans, proceeding on leave. Lient.-Col. Lieut.-Col. S. C. Evans, proceeding on ltave. Lient.-Col.
R. M. Carter, C.B., on release from military duty, has become Professor of Pathology and Morbid Anatomy and Curator of the Pathological Museam, Grant College, Bombry. Lieut.-Col. K. F. G. Tucker, first physician, Sir J. J. Hospital, and Professor of Medicine Grant Medical College, has been granted leave for five months. On reversion from military duty, Lieut. Col. C. A. Gill has resumed his former appointment of Malaria Medical Officer, Punjab. Major J. E. Clements, superintendent. Central Prisin, on reversion from military duty, has been appointed to the charge of the Lucknow Central Prison. Lieut.-Col. R. G. Turner has been transferred as civil surgeon, Fyzabad, to Mussoore. Lieut.-Col. A. W. R. Cochrane, superintendent, King Fidward VII. Memorial Sanatirium for Consumptives at Bhowali, bas been granted leave for eight months. The Government of the United Provinces has nomina ed Lieut.-Col. T. Gunter to be a member of the United Provinces Medical Council, vice Hunter to be a member of the United Provinces Medical Council, vice
Lieut.-Col. J. M. Crawford, O.B. E., resigned. Col. Hormasjee Eduljee Lieut.-Col. J. M. Crawford, O.B. E., resigned. Col. Hormasjee Eduljee Banatvala, C.S.I. has been appointed to act as Ins
Prisons, Bombay Presidency, pending further orders.

THE Oxford Ophthalmological Congress will hold its next meetings on July 10th and 11th. They will be preceded by a dinner held on Wednesday. July 9 th, in the hall of Keble College. Addresses will be delivered on the following day by Mr. Walter H. Kiep, Mr. Edgar H. Smith, and Dr. William McLean, of New York. The afternoon will be devoted to a discussion introduced by Mr. J. Herbert Parsons Further addresses will be given on the Friday and the scientific museum will be open on both days. 